\title{
Horseplay, care and hands on hard work: gendered strategies of a project manager on a construction site
}

\begin{abstract}
The discourse of managerial expertise favours rational analysis and masculine ideals but contemporary management literature also recognises the value of well-being and employee voice in the workplace. Drawing upon narrative analysis of interview data, we share unique insights into the lived experiences of Laura, one female project manager who recently managed a construction site in the Midlands in the UK. In contrast to previous research which indicates that female managers tend to conform to quite a traditional set of gender behaviours, Laura embraces a range of workplace appropriate gendered strategies, such as hard work and horseplay, together with sensitivity and caring. She draws from this mix of gendered strategies in negotiating between two different discourses of construction; one professional and one tough and practical. Her behaviour both reproduces the masculine ideals (through horseplay and heroic management) and opens up possibilities for modernising construction management (by caring). It is this combination of strategies that is at the heart of tacit expertise for Laura. Theoretically, the discussion adds to the development of a more nuanced understanding of management expertise as situated and person specific knowledge that draws on both the explicit and tacit. Specifically, the centrality of gendered strategies beyond the masculine ideals to success on site is highlighted.
\end{abstract}

Keywords: management expertise, project manager, gendered strategies, horseplay, care

\section{Introduction}

Masculine ideals and rational management dominate construction management literature. Although it is widely agreed that such an approach is oversimplified, focus on technical and explicit knowledge and expertise aligned with rational management prevails (Boyd and Addis, 2011). Not only is tacit knowledge more difficult to manage in practice as it cannot be codified, stored or distributed easily; there are significant theoretical problems with incorporating into it the objectivist knowledge management approaches which predominate in construction (Addis, 2014). Tacit knowledge is person specific and context dependent (ibid: 1247). It follows that construction knowledge is gendered: construction workers are men and women and construction sites are historically, normatively and numerically male dominated and masculine, and produce an environment that tends to uphold vertical and horizontal gender segregation and the gender binary.

Gender is discussed within the construction management literature, but too often in a comparative and defensive fashion where 'the other' is compared with the masculine ideal, or men (Ness, 2012: 671). For example, Arditi et al (2013) conclude that "female managers are as competent as male managers..." Language here re-affirms the doubt about women's place and position on a construction site instead of developing an argument for or a perception of gender-neutral 
management in construction. This trend is not unique to construction: "managerial discourses construct management as a task that requires the application of expertise and rational analysis to provide control over organisational activity and ultimately the realisation of organisational goals" (Hay, 2014: 510). The distinction between male and female and masculine and feminine tend to generally subordinate, marginalize, or undermine women with respect to men (Knights and Kerfoot, 2004: 430).

Drawing upon interview data, we share empirical material which provides unique insights into the lived experiences of Laura ${ }^{1}$, one female project manager who recently managed a construction site in the Midlands in the UK. This case shows how Laura employs a range of gendered strategies in interacting with her crew and managing the challenging site conditions and client relations. These include hard work and playing pranks, and caring. It is this combination of strategies that is at the heart of expertise for Laura. Theoretically, reflection on Laura's account adds to the development of a more nuanced understanding of management expertise. Specifically, in response to a call for scholarly engagement with construction management practices that recognises alternative analytical tools (Styhre, 2011: 953) the contribution of a variety of gendered strategies beyond the masculine ideals and rational management to success on site is highlighted. Caring strategies tend to appear less influential in management manuals such as the PMBOK (Buckle and Thomas, 2003) hence the discussion has important implications for policy and practice.

Embracing an analysis of a case study locates the discussion within an organisational situation and allows for a move away from the comparative position of an ideal and 'the other.' The analysis is not politically motivated to advance women's position in construction. Rather, it is a showcase of a unique story for advancing the discussion of expertise in construction. Arguably, adopting a mix of gendered strategies contributes to the success of a manager, and thus the ability to employ such a mix sits at the core of managerial expertise. Both women and men can develop and employ different gendered strategies to managing construction work (Buckle and Thomas, 2003: 434). The perceived gender of a manager need not be relevant. Active differentiation on the basis of gender appears to be constraining rather than advancing the move away from the binary (Chan, 2013: 818).

We share a narrative analysis of the interviews with Laura and her crew on site. Firstly, the conceptual framing which utilises the concept 'gender,' and gendered strategies in particular, is set out in order to ground the discussion of the empirical accounts second. The analysis works through the central themes that emerge as important to Laura. Discussion of the construction site begins to uncover the centrality of gender to Laura's experience on site. Laura's approach is influenced by her perception of the site as a 'tough, masculine and practical' place of work. Thus, she embraces hard work and horseplay. Her outward-facing identity work heavily draws upon masculine ideals. Parallel to that we find her vulnerable and insecure. The discussion highlights how Laura employs caring as part of a repertoire of gendered strategies at work. This way, we discover the explicit and the hidden in Laura's performance. In the conclusion, the narrative analysis is used to inform the discussion of an opportunity to open up construction expertise development to include the tacit, the contextual and gendered, and foster a modern, professional and high-tech image of managerial expertise in construction.

\footnotetext{
${ }^{1}$ a fictional name created to protect the research participant's identity
} 


\section{Gender at Work}

Gender organizes the labour market in a number of ways (Adkins, 1995). It is well-established that labour market is both horizontally and vertically gender-segregated (Hirdman, 1990; Wharton, 2012). Horizontal segregation means that there are fields that are considered typically "male" or "female" such as construction or care. Vertical segregation refers to the hierarchical organization of the labour market according to gender: male leadership is favoured and thus men more often than women occupy higher ranking positions in organizations (Chandra and Loosemore, 2004: 948). This kind of organization and division of work draws from and replicates the gender binary: an understanding that men and women are inherently different and they have their proper roles in society. The gender binary relies on essentialist thinking on gender and gender identity. It maintains culturally and socially produced norms concerning "appropriate" gender roles in society and consequently "traditional" and "natural" division of labour between the sexes.

These traditional classifications of gender (and gender roles) that are based on the gender binary tend to divide and polarise society, and thus alone provide inadequate mechanisms for understanding and managing gender in modern organisations. A more nuanced understanding of gender has emerged over the past two decades, which has developed an awareness of the problems with the binary and an essentialist understanding of gender. Probably most influential of the theories of gender is Judith Butler's notion of gender as performativity (Butler, 1990). Butler maintains that gender identity does not follow from biological sex, but that gender and gender identity are constructed discursively. Gender is not what one is, but what one does. Gender is continually produced through repetition of performative acts in our day to day lives. Performing gender does not mean same as a "performance" (ibid). How we perform gender in everyday situations and practices is not a matter of free choice, but it is always rooted in time and place and culturally and socially constructed ideas on gender and the heterosexual norm that prevail. Performativity of gender means that we replicate prevailing notions of gender by doing and speaking, and consequently this way construct gender and gender identity. However, as Butler observes, gender performance can also be subversive, incorporating subtle and not so subtle departures from the prevalent discourse (ibid: 147).

So over time, as our understanding of gender has become more sophisticated, an analytical framework has emerged which sees gender as a 'multilevel system' (Wharton, 2012). The different levels may represent identification of gender as fixed within the binary disjunction of 'being' a man or a woman; identification of the masculine-feminine binary; or, multiple and co-existing identifications (after Butler, 1990). The different levels may alternatively correspond with sociological action (after Wharton, 2012) which resides within individuals, such as their personalities, traits and emotions; social interaction, where gender is created through social interactions; or, an embedded view where gender is embedded in the structures and practices of organisations.

Employing such a 'multilevel system' to analysing gender at work allows us to examine how Laura employs a range of gendered strategies from different perspectives. The identification of gender as one being a man/ woman on the basis of individual characteristics (such as personalities, traits or emotions) has most in common with lay understanding of gender. In practice-based research close connections with the 'everyday' open up the possibilities for considerations of how research may inform practice. Being a woman is an important matter for Laura and this influences her identity work and thus management expertise. The masculine-feminine and the social interactional views 
offer a relational approach to understanding how social situations, for example interactions between the different stakeholders on site, influence gender. Laura's interactions with her crew and other stakeholders on site reveal the vulnerable and insecure, her hidden identity work. We discover Laura's use of a mix of gendered strategies in negotiating the challenging conditions on site. Butler's multiple and co-existing identifications of gender, gender as performativity, move beyond the fixed categories of gender and help reveal the ambiguous and subversive. Such analysis offers a contextual and discursive approach to understanding gender and informs the analysis of Laura's expertise beyond the binary. ${ }^{2}$ Gendered strategies offer one way of understanding gender as a multilevel system, drawing together the individualist perspective, social action and gender as performativity.

\section{Gendered Strategies}

Individuals tend to develop different types of (conscious and unconscious) gendered strategies that have different purposes at the workplace. Some of the strategies are used in order to neutralize and/or cope with possible gender bias or discrimination while others are in use to build alliances and good will.

This concerns especially women who work in male-dominated fields and/or high ranking positions (Ness, 2012: 663-664). A commonplace strategy for women is to downplay or carefully think how they express their gender and how their doing of gender reflects or rejects the normative assumptions about feminine/ masculine behaviour at work; the gender binary. Among these strategies are for example opting for gender neutral wear, restraining from behaviour or taking on roles that are considered stereotypically female/ male and emphasizing their professionalism. Sometimes women at male-dominated workplaces aim to assimilate with the male norm by trying to emulate behaviour patterns that are considered stereotypically male and act as "one of the men" (Smith, 2013: 865; Williams 1991). In organization studies, humour has been explored recently as one specifically gendered mechanism of control and power, an approach to conflict resolution and a way to develop people relationships within many professional environments, including civil engineering (Watts, 2007), advertising (Kenny and Euchler, 2012) and firefighting (Sliter et al, 2014).

While downplaying one's femininity and opting for performing gender neutrality or adopting male style speech and behaviour patterns are commonplace, it has been observed that gender and especially those strategies that are assumed to be typically feminine or female can be used as a positive resource at the workplace (Hirvonen, 2012). For example, women might use skills associated with the role of a mother, mothering, and care strategically at the workplace.

One specific aspect of gendered performance at work - a gendered strategy employed by managers - refers to management styles. There are many general classifications of management styles ${ }^{3}$, such as the autocratic-democratic-laissez faire model of management styles. Here attention focuses on

\footnotetext{
${ }^{2}$ The embedded view draws on macro-structural and institutional perspectives and relates gender to large scale patterns such as the welfare state (Wharton, 2012: 17). Such considerations are beyond the scope of this project.

${ }^{3}$ Often 'leadership styles' is used as a synonym to 'management styles' although an extensive body of literature in this field discusses the differences between management and leadership. The use of 'management' is intentional in this paper given the fit in the discussion of the empirical material.
} 
how managers make decisions and how they interact with their subordinates. Control, top down decision-making and little worker involvement are symptomatic of an autocratic management style. This suits rational management well and feeds the masculine ideal of the manager as a skilful expert (Hay, 2014: 511). In contrast, managers who adopt a laissez faire style to management tend to empower their teams, devolve decision-making to subordinates and operate 'at a distance.'

Blake and Mouton (1972) introduced task vs person centred models of management. Task orientation is often associated with 'hard' aspects of management, such as financial control. Person centred approach on the other hand focuses on the 'soft' aspects of management like motivating staff. More contemporary considerations focus on contextual/ situational styles and an authentic approach to management. The idea behind contextual/ situational management is that no one style can be applied constantly but rather managers need to adjust their management styles to suit the type of work, subordinates they employ, organisational circumstances, sector of work, etc. Ultimately, an authentic approach to management is about value based management with an emphasis on a positive stance, development and relationships with others (Rickards, 2015: 242).

Gendered interpretations of management styles often use the abovementioned general classifications and differentiate between female and male managers. In so doing they replicate the gender binary. Research evidence suggests that female managers often employ participative and people-centred styles whereas male managers tend to be more directive and task oriented (Eagly et al, 2003; Desvaux et al 2010: 5, Patel, 2013: 19). Such generalisations constrain the development of sophisticated understandings of gender and management expertise. Project management competencies have been examined using the same general classifications (see for example Cheng et al, 2005; Turner and Muller, 2005; Toor and Ofori, 2008) but very little literature is available on gender and managerial expertise in project-based work (with the exception of Styhre, 2011; and Arditi et al, 2013).

The case of Laura provides an insight into the experience of a woman who works in a high ranking position in a male-dominated field; a female project manager on a construction site. We explore what kinds of gendered strategies are in use and how Laura employs these in interacting with her crew and managing the challenging site conditions and client relations. The analysis utilises the multilevel system view of understanding gender (after Wharton, 2012) and thus draws on the individualist perspective, social action view and gender as performativity in developing a holistic appreciation of gender and expertise on the construction site that Laura manages. Before we explore Laura's lived experiences on site, an introduction to Laura and her crew and a critical discussion of the research approach follows.

\section{Research approach}

Central to the research is Laura: Laura is a project manager working for a large, 'top ten' construction contractor in the UK. Hierarchically she holds a high ranking position in the organisation and she is well respected by her superiors and subordinates. Indeed, she was recruited to the company from another contractor to manage a particularly challenging site because of her experience and suitability for the project. 
Laura manages a team of eleven staff on site: a quantity surveyor (QS), a design co-ordinator, three site agents, two engineers, a foreman, a trainee technician, a trainee $Q S$ and a secretary. They are all white men, and most in the 30-40 age bracket. The two trainees are younger in the 20-30 age bracket. One of the site agents is a long serving member of staff in the organisation with 35 years of service. He is in the 50-60 age bracket. All others are new to the organisation and have been specifically recruited to work on this project. Laura is also white and in the $30-40$ age bracket.

All the staff on site were interviewed during a site visit which lasted all day (7am-6pm) and included a tour of the site ${ }^{4}$. The interviews lasted 30-90 minutes each. They were tape recorded and later transcribed verbatim.

While this data set aided the broader understanding of the contextual richness surrounding Laura's account, and helped to build a comprehensive case study of the project, our interest is specifically on Laura and her experiences of managing the construction project and her crew on site. Close examination of Laura's approach helps us better understand how women operate in this environment through contextual and very personal discussion which developed during the interview with Laura. Focus is on the ways in which Laura talks about and actively performs gender and how the working environment in turn influences her doing gender.

This paper enlightens prior analysis of the wider data set by introducing a new theoretical and analytical lens through which we view the specific section of data in-depth. The interview with Laura was unique in that Laura really opened up and talked about her experience freely with little reservation. She shared very personal information about managing her weight and marital relationships and showed photographs of some pranks played on site.

Watson (2009) has found this kind of in-depth approach to qualitative research useful in analysing personal and professional identify work. Specifically, this approach is useful in working beyond concepts such as 'managerial identity' and understanding people's working lives and identity construction holistically. We explore Laura's outward-facing identity work (Watson, 2009: 432), and her account of life on site generally and in terms of how gender is done on the construction site.

A narrative approach was used to analyse the interview transcripts. Narratives offer a form of human understanding and sensemaking, through which individuals structure and organise their experiences of the world (Ylijoki, 2005; Polkinghorne, 1995). In social-science research, narratives are increasingly being used as a method of inquiry as well as a way of presenting results (see for example Gergen, 1994). Drawing on Polkinghorne (1995) and Lindebaum and Cassell (2012) narrative analysis was applied on the data in order to identify story lines that unite fragments of talk and build thematic narratives in the interview. Reflexive reading and re-reading of the transcripts lead to identification of key issues first, and thereafter storylines, which allowed for piecing together the narrative streams that collectively render a coherent story (see Table 1 for an example of one central theme: 'getting on with the lads'). Importantly, reference back to the full transcripts was maintained continually throughout the analysis, and related the specific narratives to the way Laura portrays her experience on site as a whole; gestalt or lifeworld (after Aarseth, 2009: 428).

\footnotetext{
${ }^{4}$ The research was conducted as part of a larger research project on people resourcing and human resource management in construction (see Raiden et al, 2009).
} 
All names have been changed to protect the anonymity of the personnel discussed.

Table 1: Narrative "getting on with the lads", related storylines and implications (after Lindebaum and Cassell, 2012: 72)

[insert Table 1 here]

The interviews with Laura and her crew provide an interesting case for analysis on two accounts: the conversations (and other data, such as the photographs shown during the interview with Laura) allow access to unique data. There are only few female project managers in construction. Also, the interview with Laura in itself is a useful source of rich data - Laura 'performs' throughout the interview showcasing the gendered strategies she employs to manage her staff. The narrative she constructs brings to the fore gendered strategies, such as achievement orientation, trouble shooting and playing pranks. At the same time, Laura engages the researcher very closely with her story by revealing personal details. She shows interest in the study and lends support for the researcher in a caring way.

However, an acknowledgement of the problems inherent in interviewing managers, especially overcoming the staged performance of positive identity talk (Hay, 2014: 510, 513), is important. Laura clearly performs the masculine managerial ideal, 'a hero' on site in places (Styhre, 2011: 947). This theme does not overwhelm the interview as a whole however, and given that there was relatively little direction from the researcher in teasing out conversation about gender and expertise (the research project was focused on understanding people resourcing and HRM) what Laura reveals about the strategies she employs to managing the site and her crew are volunteered and hence clearly of significance to her 'self.'

As much as the analysis of the interviews with Laura and her crew showcase how Laura employs gendered strategies on the construction site, we also gain an insight into the way that Laura narrates her story and how her storytelling influences our interpretation. It is this duality of understanding that allows us to reveal multiple truths about the relationship between managerial expertise and gender.

\section{Narrative analysis}

Discussion of the data is organised around three core narratives that emerged from the analysis of the interviews with Laura and her crew: the construction site, gender and work, and gendered strategies. The narratives on the construction site and gender and work first help contextualise the discussion. We explore the working conditions on the site that Laura manages and provide an overview of the gender relations relevant to this specific site. Laura's views of different professions and how these influence her doing of gender on the construction site are discussed. Within the third theme, gendered strategies, horseplay and caring arise as focal points in the discussion of how Laura does gender on site. 'Being a woman' is also relevant to understanding how Laura does gender on site and we explore Laura's ambiguous relationship regarding use of gender in social action on site. Collectively these three narratives reveal how integral a mix of gendered strategies is to the ways in which Laura manages the site, her crew and the client relations. Arguably, managerial expertise and 
construction knowledge are indeed person specific and context dependent, and importantly, gendered. However, drawing on gender as a multilevel system, we also pave way for eroding gender distinctions between man-woman, male-female and masculine-feminine (after Wharton, 2012: 241).

\section{The construction site}

At the time of the interview Laura was the project manager on a construction site where four new school buildings were being built within the grounds of an existing school. This project was one subsection of a larger project programme. The overall programme included the construction of ten schools within the Midlands in the UK, and thus was a high profile public-private-partnership.

Although Laura's team was new to the organisation there was extreme pressure to meet expected performance levels. Laura's site, section one of the overall programme, was the first section to commence. All sections were very similar in nature, and so section one was considered as an exemplar. Other sections and sub-projects could learn from the experiences gained during the planning and construction phases on section one and thus potentially achieve improved levels of performance. The pressure to perform and unproven working relationships among the new staff combined to produce power struggles and reduced team synergy at the early stages of the project. All of the interviewees reflect on these challenges during their interviews and note that knowledge of the 'company ways' (i.e. explicit knowledge of the appropriate processes and procedures) would have been beneficial.

The context in which the work is done, this particular construction site, appears immensely important in the interview with Laura and many of her team members too. Much of the interview with Laura loops around and back to the site conditions, the local area and the client. The storylines build a narrative around 'difficult site and demanding work' which evolves from the physical constraints of operating and managing work on site. The construction work is expected to continue on schedule while pupils in the schools take lessons and sit exams, which interfere with site work. As a result, the working hours are very long. Laura has put in place a shift system to ensure timely completion of the work. Her crew respects her hands on involvement:

"...when we completed the infant school out there we were here until half past one in the morning. And I only had to do one night. I just dipped in with the cleaning work. But Laura was here two nights. This is the difference here." (Design Co-ordinator)

Beyond the physical conditions on site, and very hard work (see Smith, 2013: 863), Laura finds the locality challenging. The site is located within a deprived geographical area with intense social challenges. Laura makes frequent reference to vandalism on site and contact with drugs.

Importantly, early on in the interview Laura also begins to build a storyline around the Head Teachers as representatives of the client and future users of the facilities on site. One Headmistress is considered particularly challenging. Laura discusses how the school's staff are stressed and how the Headmistress threatens her with the press if negotiations are not likely to achieve favourable outcomes.

Laura's crew also comment on the challenging client relations but mostly from a technical point of view. The QS discussed the many design changes that were requested throughout the building phase 
and the delays these introduced to project delivery. One Site Agent said quite resentfully: "this is a very awkward job you see, frustrating, very frustrating." Others masked the challenges using humour and laughter. The different ways in which Laura and her staff talk about the Headmistress reveal an undercurrent of the 'structure of no complaints' (after Paap, 2006: 148). The general culture and working environment in construction often demands that workers must "handle it" and get on with the job despite poor working conditions and sometimes challenging client relations, like here. While Laura's crew members note the issue, it was only Laura who seemed troubled by it. She appears vulnerable to the threats, but quickly retracts and positions herself on par with the Headmistress:

"...she is very forceful woman, I am probably very much alike actually, which is why we don't get on."

Here Laura connects with the Headmistress and identifies the problem in their relationship being linked to the similarities in their ways of being. Gender is created through social interaction but Laura's interpretation is also influenced by the individualistic view; the characteristics and behaviours of both herself and the Headmistress. Throughout the interview forcefulness emerges as central to the way Laura manages construction work, yet Laura finds forcefulness as a characteristic in the Headmistress negative. Forcefulness is often associated with an autocratic management style and achievement orientation, two characteristics that may be perceived as masculine. Laura's aversion towards the Headmistress could be explained by gender bias. The 'everyday' is rarely immune to the normative gender expectations at the workplace. Laura gets along with those Headmistresses that could be perceived as behaving in a more conventionally "feminine" style and thus align with her expectations of the teaching profession and women at work. The Headmistress that incorporates "masculine" coded strategies in her repertoire is breaking some of the rules of normative gender behaviour. This Headmistress introduces an element of competition. The other Head Teachers, male and female alike, are described using distinctly positive and emphatic tones. They conform to the expected norms and hence do not pose a threat to Laura.

However, taking gender as performativity as the lens through which the relationship between Laura and the Headmistress is examined, one might argue that this constitutes a clash of personalities and is in fact very little to do with gender. Identification of gender as multiple and coexisting patterns of behaviours may here draw on the emotive response of Laura to this workplace situation and not only that which is explicitly addressed, the forcefulness. Thus 'gendered' becomes less about the fixed categories, like masculine-feminine, or the horizontal segregation of work, and focuses attention onto the workplace and broader range of considerations at play. Research on toxic workplaces and toxic personalities at work for example found no significant differences in the gender of toxic individuals (Kusy and Holloway, 2009: 9). It is the behaviour of the individual that makes a significant difference. Shaming is one major type of toxic behaviour at the workplace (ibid: 42) and the threat of shaming Laura's project is troublesome for her. So we begin to open up the ambiguities and insecurities in Laura's performance on this construction site. 


\section{Gender and work}

As a manager Laura highlights 'toughness' as one of her core strengths. On more than one occasion she refers to what she believes to be others' perception of female managers: less able or pushovers. For example, an incident of conflict with a subcontractor was discussed during the interview:

"I told them - visitors coming to look at it at two o'clock and he says 'well, I have got stuff to do in there'... 'I shall be working right up to the two o'clock'. I says 'no you won't, you can get your stuff and-' and he went 'you best explain your higher management'... I stood there and - I said 'I am the management! Get your stuff and get out!' - Just assumed because I was female I wasn't going to, you know. Gave me great satisfaction..."

This storyline uncovers issues with control, power and gender. The example reveals Laura's own traditional views of gender roles at work, specifically when considered together with a passing comment she made elsewhere during the interview: "Not that I am sexists but my secretary is male... the last thing I want to expect..." Her approach to managing the incident also further exposes Laura's insecurities. Paap (2006: 76) explains that proving oneself is something one must always attempt but can never achieve. Uncertainty of status is difficult for everyone, but especially so for women who often experience the double bind: fighting gender bias is contested but not standing up to yourself is criticised too (Paap, 2006: 4; Denissen, 2010). Laura has taken a stance to fight for her position and uses aggressive ways to front her less secure self. Her recalling of this situation brings to light how gender is created through her interaction with the subcontractors and how such situations in turn influence her management style and behaviour on site. Gender is constructed at the level of social action. However, Laura's reading of that interaction also focuses on her 'being a female' although no explicit references to gender were made by the subcontractor. Laura exhibits reliance on the male-female binary elsewhere in the interview too - we return to this discussion later.

With regards to gaining respect from her team Laura talks about an empowering management style and how her team has come to appreciate her support. In discussing her management style Laura projects a deliberately aggressive image of herself at work. She showcases herself as 'the hero,' the strong expert with guts to stand up to arguments. This is typical of managerial positive identity talk. It is not explicitly gendered. Such behaviour may be exhibited by any manager, at times. Analysis of gender as performativity indeed suggests that it is these kinds of acts that continually produce gender in the workplace, neither clearly feminine nor masculine. Rather the ways in which situations are managed may be more closely aligned with a particular management style.

However, Laura highlights her toughness on a number of occasions, and often in contrast to both her workers and the teachers who work at the schools on site. Laura's use of language is also subtly gendered and her framing of narratives implies her need to prove herself. When Laura contrasts her style with that of "her lads" in a way that promotes her forcefulness and plays down her workers' ability to stand their ground, gender is implied, as shown in the following excerpt:

"... a load of tarmac had been put down, that had been on for Saturday, cancelled, turned up yesterday, and none of our lot have got the balls to tell them to go away. So they tipped it..."

Talk about 'balls' on site is a cultural expression of strength but also a language based indicator of one belonging to the inside group (Paap, 2006: 93-94). Women's participation on site work is not easy nor always welcomed but some extraordinary women can become "one of the guys" (ibid: 92). 
Laura's behaviours and use of language all affirm her intent and wish to gain an insider status within the male dominated construction team.

One of the ways in which Laura reinforces her intent to firmly establish the insider in construction status is by contrasting the working conditions on the building site with teaching as a profession. Laura puts down the nature of their work and type of personnel teaching attracts:

“...don't never socialise with teachers, very boring. They have come from school to college to university, to back into the school environment and they have got no idea about reality and work. They work from half past eight 'til quarter past three and that is a long day, that's hard day. We work from seven in the morning 'til about half eight/ nine o'clock at night seven days a week... Having a laugh, aren't they."

Conceptually Laura's accounts of the site environment connect with literature on high satisfaction on completion of a challenging job, the intrinsic rewards gained, together with explicit pride in the nature of work, occupation and industry (see for example Dainty et al, 2005). It is this intense pride and sense of achievement as a result of survival in that tough environment that uncover Laura's value base and working class masculinities. Her view of teaching is clichéd and represents an attempt to legitimise her own overworking and drive to achieve. This is likely to be a part of Laura's subconscious strategy to survive; evidence of careful negotiation of the fine balance between coping and stress harmful to health. It is likely that some of the expressed perception of women as less able or pushovers is linked to Laura's confidence and self-esteem as she expresses great satisfaction when she can show what women really can do. Laura's conceptualising of gender at work appears closely aligned with the individualistic view of 'being a woman' but also draws on the social action perspective. Gender as performativity emerges through her use of language and the implicit references to her ways of responding to situations on site. Discussion on Laura's gendered strategies follows.

\section{Gendered strategies - humour and horseplay}

Humour and horseplay, two gendered strategies that are often perceived as masculine (Watts, 2007), and later caring, a gendered strategy commonly perceived as feminine, arise as focal points to showcase the multiple and co-existing identifications of gender.

Laura smiles as she reflects back on four humorous events:

"...one of the technicians left... we had a whip around for him, I got over 100 quid, do you know what I mean. And took him out for a drink and that. Played him a bit, set him on the road [tied to a chair; Laura shows photos], and after we put a big sign out saying '- if you love' and left him there for about two hours."

"I mean I have chased my staff round the site with fire extinguisher and I absolutely covered them. They have been absolutely covered in foam. You know, after work. But we have had the biggest laugh ever."

"Raymond went away on a course. We got young Alex, laid him on the floor, drew around him... barriered a tape across his door 'crime scene' so he had to break in to open the door. 
He would just basically open the door and see his body like this - I got his coat, I got the inner sleeves, I were not on my own, mind! That was my idea but... Pulled this out of his coat [showing the inner sleeves of a similar coat in her office], wrapped it with tape and he was trying to put his coat on [she is demonstrating wriggling around]... he had left his boots as well and his socks in them and I got some banana and Kiwi fruit and mashed them and put them in his socks. Put sand in his pockets and that sort of thing. So we do have a good laugh in here."

This is followed by a brief exchange between Laura and the interviewer:

"Laura: When Dave went on a holiday he took his boots, his hat, his coat. Interviewer: Oh no, he was prepared. (laughing)

Laura: Yes. (laughing) Because he knew what we'd do."

Laura's description of these humorous events on site opens up with a straightforward everyday example of a collection for someone leaving. This shows that despite the initial difficulties in getting new people to work together as a team, Laura and her crew have learned to appreciate each other's contribution and express their thanks to the technician with generous donations towards the collection. Quickly the tune changes however and the events portrayed quite possibly construct unlawful conduct at work. However, because humour and playing pranks do not officially count people often take risks with the implicit understanding that these events will not later be called for formal account (Watts, 2007). Laura's team members agree that 'the craick' on site is good:

"Yes, it is a good craick. ... I think this team I work with, very good sort of atmosphere. Everyone does seem to sort of get on well within this particular team. I am happy with that." (Engineer)

Playing pranks is related to a serious organisational issue to do with team building and staff morale, and Laura makes a point about the balance between keeping work enjoyable and getting the job done. Laura achieves this through the use of humour and playing pranks which evidence gendered strategies at play that are often identified as masculine (Watts, 2007). This is together with the overall forceful, aggressive and achievement oriented style discussed above. Laura swears on occasions and literally shouts through the walls in the Portakabin offices to gain the attention of her workers during the interview. Language employed to talk about life on site is place appropriate. How Laura addresses her workers may not be considered generally appropriate, and would be offensive within a clean office environment, but in this environment it connects the team and opens a window for the female project manager to join in with the lads. This is a gendered strategy that works well for Laura. She performs to fulfil both the rational task oriented management expectations and arouses camaraderie within the team. By employing this range of gendered strategies one might argue that Laura behaves like a man in a man's world as thus gains acceptance within the extraordinary category of women as an 'honorary man' (Paap, 2006: 92). This perspective relies on the individualistic and social action based views on gender. Drawing on gender as performativity, this is a showcase of a respected and accepted team manager. Indeed, beyond the labelling of humour and playing pranks as masculine gendered strategies, there is no identification of gender in these examples. Elsewhere Laura often brings up her gender identity as being fixed within the binary disjunction, being a woman, but not here. Indeed, Laura does not employ these types of gendered 
strategies exclusively. She uses them in combination with caring strategies in order to manage difficulties on site as discussed next.

\section{Gendered strategies - caring}

Talking has been an important management tool for Laura; she has used it to build a sense of belonging within the team on site:

"...we had couple of nights out. But I think the thing that we do most is after, when it has calmed down a bit on the night, we'll sit and have a chat - end up in this office, or I will end up sat on Dave's desk, you know, we'll sit and talk through the day..."

Laura also actively considers the site workers' personal circumstances and offers support by using caring strategies. She identifies gender as the enabler for this strategy:

"I know Darren is stressed at the moment. I am very conscious Darren has got a lot pressure at the moment, and because I am conscious of that and Darren is in and I come in and then I see it, I go and do work with him and I take the work of him. Although it does increase my workload, my jobload. If I don't take the work off though (a) it won't get done and (b) he is gonna crack. You know, the last thing I want is him walking out that door because he is gonna go. So got to be able to sit back and recognise when your staff is stressed and when they are happy. And I think because you are a woman you can recognise that."

Sharing difficulties, attending to personal issues and needs and recognising stress are all important to Laura. Aligned with the individualistic perspectives on gender and the gender binary, Laura offers an explicitly gendered perspective here: to her taking a person centred-approach to managing her crew is possible because of her gender, being a woman. This reinforces Laura's traditional view of appropriate gender roles. Caring strategies are characteristically associated with women and maternal behaviour. Traditional gender roles maintain the culturally and socially produced norms about women's and men's role in society: women as carers and homemakers and men as breadwinners at work.

However, caring behaviour is often also symptomatic of the 'older bloke' on site, on this site Tony, who looks out for the younger boys. Tony adopted an informal mentor role especially during the initial stages of the project when the team members who were new to the organisation were learning the company processes and procedures. Hence, developing the analysis beyond the traditional gender roles and the gender binary, and employing more sophisticated tools on gender allows us to consider the activity and unearth the subversive which moves beyond the fixed categories. Caring strategies have been an important element of management for both Laura and Tony, hence to label them as specifically relevant to one gender or another would be misleading. Contemporary models of management styles consider such a people-centred management style a possibility regardless of the gender of the manager, although rational management tends to dominate the field.

Laura offers one example that indicates how she has created an atmosphere on site where relationships between her and her crew, and amongst the crew, grow: 
"...Tony will come in and if he is feeling a bit down - I'll say 'not feeling that good today kid?' And the lad's will go out of their way to have a laugh and a joke to pull him back up. But it wasn't until he explained what the question is - 'I am depressed, I am pissed off' - It wasn't until he explained what happens to him, that we could all appreciate. I mean sometimes I go - com' on, well have a walk around the site - So he feels his worth. I spoke to his wife - and I had trouble with my stomach and so does his wife. So where as we are looking after Tony and his depression, they'll come to me and - 'you look a bit...' They can tell if I have been sick or not because I have the pain - And they go over to Tony's wife and say Alison wasn't very well today and she'll be 'oh, how have you been', because she has got the same sort of problem..."

Much is packed in this excerpt: 'soft' management, attending to personal issues sensitively, involving workers' family, caring behaviour, and a sense of belonging, to highlight those of interest and importance here. Caring diversifies Laura's use of gendered strategies as a mechanism to create a sense of belonging and team spirit. It highlights the necessity to employ tacit knowledge and intuitive questioning to tease out problems.

By using caring as a management strategy Laura has established a two-way connection between herself and her crew. She notes that "... now they are taking interest in my life as well. It's like having our little community really." Laura also expresses the communal feel that has developed on site with reference to a family: "...even down to the security guy, Albert. Albert has been here from day one, he is like part of our family."

The storylines related to the site team are laden with emotive statements and discussion about how Laura connects with the personal lives of her workers. She very strongly exhibits a sense of ownership, using "I have", "my lot" and "my lads". She portrays herself as the head, explaining how her role and nature of work differs from those of 'the lads': "I do my work-managerial, the lads are bit more hands on..." It is clear that she is keen to differentiate herself as the head of the family. Spatially family is closely connected with the home, "a place where individuals can assert their identities and 'be' what they want to be" (Holloway and Hubbart, 2001: 90). Traditionally home has been designated as a woman's place to be, one environment that they can control (ibid: 91). Laura's behaviour and outward-facing identity work suggests that she uses her maternal caring strategies, mothering, to establish a sense of belonging, but also control, on site.

Other team members on site refer to family too:

"I get the feeling here it is almost like a little family. Looks like a family. Everybody is the same, so good with each other. I have just moved house. I had a week off to move. I came back and everybody had a collection for me... It was really nice. Yes, definitely, everybody gets on really well. I mean there is little cries here and there but it all comes to the open and it gets sorted out. That's the main thing." (Trainee QS)

In terms of sensemaking regarding the storyline 'site team as a family' strong ownership of the site and explicit commitment to project team stand out. Laura pays attention and care to her team which extend beyond professional boundaries and the crew all look out for each other and Laura too. This is a caring strategy at play. Laura relates the level of interest the team members show in her life to a 
sense of achievement and belonging; a bond between the project manager and her team members. 'Community' and 'family' are used to express this sense of belonging.

This is interesting given that 'normal family life' in construction environment can be difficult to maintain because of the transient working relationships and long working hours. Indeed it is likely that the harsh conditions serve to strengthen the bond between the workers on site. Laura reflects:

"You got to be a certain breed of a person. I mean I am divorced. My ex-husband could not understand that, why I was on site at nine o'clock at night - work to do. I mean I work here on a night, not every night, Wednesday night is a fat farm night so I would be out quarter past five, but generally is about seven to half past."

It is clear to Laura that the long working hours especially often distort personal relationships outside of work. This may well motivate her to invest in the relationship with her crew and build the temporary community/ family for her to belong to and control.

Two competing interpretations emerge from within this theme: caring as a female gendered strategy and caring as a gender neutral performative act of good site management, or managerial expertise. The latter aligns with Butler's analysis of gender as multiple and coexisting identifications where a given strategy is not explicitly nor in a fixed way connected with the gender binary. Rather it is possible that individuals employ a range of gendered strategies; gender is constructed by what one does. The former, caring as a female gendered strategy, more closely accords with Laura's view of gender.

Laura emphasises the role her gender identity plays: "I would say the fact that I am a female helps." Laura embraces her gender as an advantage. It allows her to 'be different', to talk about feelings and be open about problems. This goes against the grain of the aforementioned 'structure of no complaints' (after Paap, 2006: 147) and thus being female opens up a possibility for Laura to engage her staff emotionally. Although much of Laura's performance is concerned with fitting in and trying to be one of the boys, her talk about being a woman entails a 'soft' side. This form of gender management is situationally constituted and used to manipulate the rules for one's own advantage (Denissen, 2010). The soft side is only one side to Laura's discussion about gender however. Her talk about gender in terms of her workers (men) using their gender with one (female) Headmistress vs Laura herself using her gender with her workers reveals further insight into Laura's view of gender roles:

"...and she is, I wouldn't say she is anti-female but she is very into nice young men. You know the lads can go in and look. They lads can do with her what I do with the blokes. You know, if we have got a problem, and let's say Dave is having a nightmare with the subcontractor wanting them to do extra work and rowing - They'll come in and see me. One of the best things about a woman, is using the fact that you are a woman. Because l'll sit here saying 'please'. And the men can't help themselves. They like to be a knight and shining - you know charging to my rescue. And I can get away with a murder. I can get away with absolutely anything. And they do the same sort of, not to the degree I do, but they'll go and look at her straight in the eyes and you can see her just giving in and you think 'hmph, pathetic'." 
While there is evidence to support the traditional views of gender roles Laura has projected elsewhere too, there is also an indication of a curious disapproval of the other woman's response to 'male power'. Laura has an ambiguous relationship regarding female gender performance in a management position. She shows appreciation of both normative male and female behaviour at the workplace, but also disapproves quite strongly the use of femininity as a strategy. Laura's interpretation of gender draws on both the individualistic view, being a woman or a man, and the social interactionist approach. In her view the categories of woman and a man are relatively fixed and ought to conform to the culturally and socially constructed ideas of how the two groups may interact with one another. This reproduces the gender binary, yet in doing gender Laura's performance incorporates subversive and subtle departures from the prevalent discourse.

\section{Discussion and Conclusion}

The analysis of Laura's account of life on site provides a two-fold contribution: we share unique empirical material about the world of work on site, and theoretically add to the development of a more nuanced understanding of management expertise. Specifically, the centrality of a mix of gendered strategies to success on a construction site is highlighted.

The sex/gender of the respondents was not a selection criteria for choosing the participants for the original study nor did the semi-structured interview schedule include questions or probes which may have brought about discussion on such themes. All references to gender in the interview with Laura were initiated and maintained by her. This was clearly a major issue for Laura; being a woman cannot be separated from her work as a project manager and thus her identity work is explicitly gendered (in line with Kyriakidou, 2012: 854).

Laura is a successful manager, yet it is evident that she works to an internalised comparative "as good as a man". This presents a double bind, an impossible to achieve goal (Paap, 2006; Denissen, 2010). Laura holds very traditional gender ideals and a value system based on working class masculinities, and expects others to closely conform to such a view. This is evident in how Laura thinks others perceive female managers and also her view of the Headmistress on site. Many times Laura takes pride in showing what women can do, putting forward very positive identity talk of herself as the heroic manager, strong and able to solve all ills on site (after Hay, 2014; Styhre, 2011). Although she identifies herself as a woman on site, a marginalised and minority identity, she places herself firmly at the centre of the operation with "her lads". She rejects 'being the outsider' and highlights her gender identity as advantageous (see Kyriakidou, 2012). This allows her to work outside the usual confines of 'managerial identity' which includes for example the implicit suppression of emotion (Hay, 2014: 511, 513). She exhibits high level of self-esteem and confidence in the world of work, at least in her outward identity work, which accords with Chandra and Loosemore's (2004) study of women's self-perception in construction, nursing and the legal profession. At the same time, research echoes concerns about the grandiose managerial discourse as the dominant voice that silences emotions in managerial identity work (Hay, 2014: 519). Underneath the surface Laura appears vulnerable and insecure. Her management strategies are often employed to mask this. This implies a need to understand managerial expertise beyond the masculine ideals and rational management. Revealing the human, the tacit knowledge and 
contextualised expertise that help gel new members together as a team and offer an opportunity to engage with workers' well-being, as well as productivity, is important to changing the culture of construction.

'Gendered strategies' were presented as a way of conceptualising multiple and coexisting identifications of gender in managerial work. The intention has been to move away from the gender binary that relies on essentialist thinking and maintains norms concerning gender roles. Therefore, the ways in which Laura does gender on the construction site, and how gendered organisational practices in turn influence her doing of gender are discussed next.

Laura uses a mix of gendered strategies. She exhibits a heightened sense and awareness of her workers' personal lives. She actively uses caring as a tool to maintain high staff morale on site. Laura also employs gendered strategies aligned with achievement orientation: she refers to the need to do/ complete the job frequently, her language is very tough and there is an excessive emphasis on fun (horseplay). Laura is making sense of the site experience by playing pranks to keep the difficult work conditions enjoyable. Humour is an important coping strategy in face of the stressful site conditions, new team and demanding client. These gendered strategies allow her to fit in. However, it is not only gender that is at play here. Ness (2012: 670) and "a complex interweaving of class and gender" offer some explanatory power: Laura's value system, which is based on working-class masculinities, and the harsh site conditions influence Laura's interpretation of place appropriate behaviour. Laura transitions between two discourses of construction: one as a modern, professional and high-tech; and the other as uniquely tough, masculine and practical (ibid: 662). The former allows for expression of the managerial identity and caring, while the latter signals the appropriateness of horseplay. Laura's differentiation between her work as "more managerial" and that of her lads being "more hands on", together with her putting down of teaching as a profession, all point to a strong sense of working class masculine values. "Real work" (after Ness, 2012: 661) is about long working hours, surviving within difficult conditions and completing a challenging job. Laura takes pride in "swinging a sledgehammer".

'The tough, masculine and practical' discourse influences Laura's performance of gendered strategies that fit the environment: hard work and horseplay. Much of the data from her crew supports this approach. However, this is not always successful. When Laura plays pranks to strengthen the camaraderie within her crew we note the resistance from a professional member of the team. The QS who takes all his belongings with him on holiday in fear of pranks being played in his absence is likely to buy into the modern, professional image of construction and a more middleclass value system. Taken alone, this instance supports Styhre's (2011: 952) finding that personnel on site are "bound up in modes of thinking that are blocking a more modern view of site management." However, Laura recognises that really what makes most difference in her style of managing are the caring kind of strategies. She uses the caring strategies to assess her workers' frame of mind and adjusts the working conditions accordingly.

This mix of gendered strategies portrays gender as a dynamic and multivariate construct and highlights the centrality of a diverse range of gendered strategies to managerial work. To Laura, managerial expertise is gendered in very complex ways. The interview with Laura is refreshingly different, an open and honest account of her lived experiences on site. She is an authentic manager placing much emphasis on relationships with others. 
In contexts where gender differences are extreme, such as on the construction site, moving away from the gender binary is difficult. Despite decades long legislative measures, equal opportunities policy and initiatives, and attempts to change the culture of the industry, little improvement in women's participation in construction work has been achieved (Paap, 2006; Ness, 2012; Chan 2013). Certainly, many special campaigns and efforts to recruit more women into construction endorse the gender binary and hence hinder the achievement of a balanced view of management (and work more generally) in construction. For example, linking together the arguments that there is a need to change the culture in construction, a need to deal with the tough jargon used on construction sites and setting up of support networks for women, collectively send a message that this group of workers needs assistance and hence do not operate at the same level as men. This only serves to reinforce the types of attitudes Laura highlights in her interview (women=less able) and thus maintains the gender binary. The efforts may be well intended but reproduce the dominant ideology that construction work is men's work (Ness, 2012).

Observations and analysis of Laura on site and the ways in which she interacts with her crew and other stakeholders related to the project allows us to deepen our understanding of the relationship between managerial expertise and gender. Laura's account runs counter to the findings of Arditi et al (2013) which indicate that female managers in construction, at least in Sweden, tend to conform to quite a traditional set of female gender behaviours. Laura embraces gendered strategies that are complex, not always distinctly masculine or feminine but often about different management styles. This mixture showcases contextual, adaptive style of management. Laura's experience shows that horseplay, care and hands on hard work are all important and central elements of success on site.

Butler's notion of gender as performativity has been criticized for a failure to address the role of context and space where the performance takes place (Lloyd, 1999: 196-197). In this sense Laura's narrative offers an interesting case for analysis that is clearly contextualized within a normatively gendered environment. Laura performs and thus constructs gender by doing and speaking within the normative constraints of prevailing gender expectations and the heterosexual matrix. However, Laura's gender performance is complex. She draws from a mix of gendered strategies in negotiating between the two different discourses of construction; one professional and one tough and practical. Her behaviour both reproduces the masculine ideals (through horseplay and heroic management) and opens up possibilities for modernising construction management (by caring).

Contemporary, sophisticated and multilevel understanding of gender advocates that in order to achieve gender equality, we must strive for gender to matter less. Using specific examples from the interview with Laura, we have uncovered how the multiple and co-existing identifications of gender expose the fundamental unnaturalness of the gender binary (after Butler, 1990: 149). Gender becomes just gender. Management expertise begins to draw on a balanced set of skills and behaviours that may be applied sensitively depending on the contextual circumstances. Gender disappears as a matter of relevance, and focus shifts onto strategies that employ caring, horseplay and hard work. Focusing attention on the specific management strategies may ease the theoretical problems that Addis (2014) identify regarding incorporating tacit management of expertise with the objectivist knowledge management approaches which predominate in construction currently.

This has implications for construction policy and practice: management manuals and industry policy discourse must be revised to more explicitly integrate the human, the tacit, the contextual and 
professional ways of managing construction work. The challenge that remains is centred on transfer of knowledge to inform practice on site.

The analysis of Laura's account features a theory-practice divide. While gender may be theorised at the level of sophistication offered by Butler's multiple and coexisting identifications of gender, in practice it is often the individualistic view and relatively fixed categories of male-female or masculine-feminine that drive thinking and behaviour. Thus, the ideal may theorise expertise as gender neutral but a more realistic framework ought to account for the 'everyday'. Theorising of gender has advanced to a level where nuanced and sophisticated analysis is possible and commonplace. To achieve culture change where gender disappears as a matter of concern for management expertise on construction sites remains the challenge. How we perform gender is not a matter of free choice but always rooted in time and place and culturally and socially constructed ideas on gender and the norms that prevail. Further research in this area might study gendered strategies in relation to professionalism, the nature of work, working conditions, identity and/ or belonging in order to develop our understanding of the everyday and how changing social norms influence doing of gender on site. A structured methodology that focuses on collecting data on these issues specifically would allow researchers to unearth further insights on the kinds of gendered strategies in use on site and also engage larger sample sizes.

\section{Acknowledgement}

The development of the conceptual framing regarding gendered strategies is thanks to Hannele Harjunen, University of Jyväskylä, Finland.

\section{References}

Aarseth, H. (2009) From modernized masculinity to degendered lifestyle projects: changes in men's narratives on domestic participation 1990-2005, Men and Masculinities, 11, 4, 424-440

Addis, M (2014) Tacit and explicit knowledge in construction management In: Raiden, A B and Aboagye-Nimo, E (Eds) Procs 30th Annual ARCOM Conference, 1-3 September 2014, Portsmouth, UK, Association of Researchers in Construction Management, 1245-1252

Adkins, L. (1995) Gendered Work: Sexuality, Family and the Labour Market, Buckingham: Open University Press

Arditi, D., Gluch, P. and Holmdahl, M. (2013) Managerial competencies of female and male managers in the Swedish construction industry, Construction Management and Economics, 31, 9, 979990

Blake, R.R. and Mouton, J.S. (1972) The managerial grid, Houston, Texas: Gulf Publishing Company

Boyd, D. and Addis, M. (2011) Moving from knowledge management to expertise management: a problem of contexts, Working Paper Series, no. 3, Centre for Environment and Society Research, Birmingham City University, ISBN 978-1-904839-46-0 
Buckle, P. and Thomas, J. (2003) Deconstructing project management: a gender analysis of project management guidelines, International Journal of Project Management, 21, 433-441

Butler, J. (1990) Gender Trouble: Feminism and the Subversion of Identity, London: Routledge

Chan, P.W. (2013) Queer eye on a 'straight' life: deconstructing masculinities in construction, Construction Management and Economics, 31, 8, 816-831

Chandra, V. and Loosemore, M. (2004) Women's self-perception: an inter-sector comparison of construction, legal and nursing professionals, Construction Management and Economics, 22, 9, 947-956

Cheng, M.-I., Dainty, A.R.J. and Moore, D.R. (2005) What makes a good project manager? Human Resource Management Journal, 15, 25-37

Dainty, A.R.J., Bryman, A., Price, A.D.F., Greasley, K., Soetanto, R. and King, N. (2005) Project affinity: the role of emotional attachment in construction projects, Construction Management and Economics, 23, 3, 241-244

Denissen, A. (2010) The right tools for the job: Constructing gender meanings and identities in the male-dominated building trades, Human Relations, 63, 7, 1051-1069

Desvaux, G., Devillard, S. and Sancier-Sultan, S. (2010) Women leaders, a competitive edge in and after the crisis, McKinsey \& Company

Eagly, A.H., Johannesen-Schmidt, M.C. and van Engen, M.L. (2003) Transformational, transactional, and laissez-faire leadership styles: A meta-analysis comparing women and men, Psychological Bulletin, 129, 4, 569-591

Gergen, K. J. (1994) Realities and relationships, Cambridge, MA: Harvard University Press

Hakim, C. (2011) Honey money - the power of erotic capital, London: Allen Lane

Hay, A. (2014) 'I don't know what I am doing!': Surfacing struggles of managerial identity work, Management Learning, 45, 5, 509-524

Hirdman, Y. (1990). Genussystemet (The Gender system). In Demokrati och makt i Sverige. SOU 1990:94. Stockholm.

Hirvonen, H. (2013) Doing gendered and (dis)embodied work. Care work in the context of medicomanagerial welfare state, Nordic Social Work Research, DOI:10.1080/2156857X.2013.867895

Husso, M. and Hirvonen, H. (2012) Gendered agency and emotions in the field of care work, Gender, Work and Organization, 19, 1, 29-51

Kelan, E.K. (2010) Gendered logic and (un)doing gender at work, Gender, Work and Organization, 17, 2, 174-194

Kenny, K. and Euchler, G. (2012) 'Some good clean fun': Humour, control and subversion in an advertising agency, Gender, Work and Organization, 19, 3, 306-323

Knights, D. and Kerfoot, D. (2004) Between Representations and Subjectivity: Gender Binaries and the Politics of Organizational Transformation, Gender, Work and Organization, 11, 4, 430-454

Kusy, M. and Holloway, E. (2009) Toxic workplace! Managing toxic personalities and their systems of power, San Francisco: John Wiley \& Sons 
Kyriakidou, O. (2012) Fitting into technical organizations? Exploring the role of gender in construction and engineering in Greece, Construction Management and Economics, 30, 10, 845-856

Lindebaum, D. and Cassell, C. (2012) A contradiction in terms? Making sense of emotional intelligence in a construction management environment, British Journal of Management, 23, $1,65-79$

Lloyd, M. (1999) 'Performativity, Parody, Politics', Theory, Culture \& Society, 16, 2, 195-213

Muhr, S.L. (2011) Caught in the gendered machine: on the masculine and feminine in Cyborg leadership, Gender, Work and Organization, 18, 3, 337-357

Ness, K. (2012) Constructing masculinity in the building trades: 'Most jobs in the construction industry can be done by women', Gender, Work and Organization, 19, 6, 654-676

Paap, K. (2006) Working construction, New York: Cornell University Press

Patel, G. (2013) Gender differences in leadership styles and the impact within corporate boards, Commonwealth Secretariat

Polkinhorne, D.E. (1995) Narrative configuration in qualitative analysis, Qualitative Studies in Education, 8, 5-23

Raiden, A.B., Dainty, A.R.J. and Neale, R.H. (2009) Employee resourcing in the construction industry, Abingdon: Taylor and Francis

Rickards, T. (2015) Dilemmas of leadership ( $3^{\text {rd }}$ ed.), Abingdon: Routledge

Sliter, M., Kale, A. and Yuan, Z. (2014) Is humor the best medicine? The buffering effect of coping humor on traumatic stressors in firefighters, Journal of Organizational Behavior, 35, 257-272

Smith, L. (2013) Trading in gender for women in trades: embodying hegemonic masculinity, femininity and being a gender hotrod, Construction Management and Economics, 31, 8, 861873

Styhre, A. (2011) The overworked site manager: gendered ideologies in the construction industry, Construction Management and Economics, 29, 9, 043-955

Toor, S.-R. and Ofori, G. (2008) Leadership for future construction industry: Agenda for authentic leadership, International Journal of Project Management, 26, 6, 620-630

Turner, J.D. and Muller, R. (2005) The project manager's leadership style as a success factor on projects: A literature review, Project Management Journal, 36, 1, 49-61

Watts, J. (2007) Can't Take a Joke? Humour as Resistance, Refuge and Exclusion in a Highly Gendered Workplace, Feminism \& Psychology, 17, 2, 259-266

West, C. and Zimmerman, D.H. (1987) Doing gender, Gender and Society, 1, 2, 125-151

Wharton, A.S. (2012) The sociology of gender ( $2^{\text {nd }}$ ed), Chichester: Wiley-Blackwell

Williams, C. L. (1991) Gender Differences at Work: Women and Men in Non-traditional Occupations, Berkeley: University of California Press. 
Ylijoki, O-H. (2005) Academic nostalgia: A narrative approach to academic work, Human Relations, $58,555-75$ 